\title{
Soil Clay Mineralogical Phase Analysis of Ganges Floodplain Soils by XRD and XRF
}

\author{
Shamiha Nazmin, Anindita Das, Md. Zulfikar Khan, Md. Sadiqul Amin, Md. Hanif* \\ Soil, Water and Environment Discipline, Khulna University, Khulna, Bangladesh \\ Email: *12hanif@gmail.com, hanif@ss.ku.ac.bd
}

How to cite this paper: Nazmin, S., Das, A., Khan, M.Z., Amin, M.S. and Hanif, M. (2019) Soil Clay Mineralogical Phase Analysis of Ganges Floodplain Soils by XRD and XRF. Open Journal of Soil Science, 9, 298-312.

https://doi.org/10.4236/ojss.2019.912019

Received: October 25, 2019

Accepted: December 28, 2019

Published: December 31, 2019

Copyright $\odot 2019$ by author(s) and Scientific Research Publishing Inc. This work is licensed under the Creative Commons Attribution International License (CC BY 4.0).

http://creativecommons.org/licenses/by/4.0/

\begin{abstract}
Soil minerals study is vital in terms of investigating the major soil forming compounds and to find out the fate of minor and trace elements in soils. It is also essential for the soil-plant interaction purpose. To identify soil mineral phases especially clay minerals, X-ray diffraction (XRD) has been a popular technique. The clay mineralogical information of soils in Bangladesh is limited, especially in Ganges flood plain region (Agro Ecological Zone (AEZ) 12 and 13). Therefore, to overcome this limitation, in this study, we performed XRD analysis of $<2 \mathrm{~mm}$ fractions soil samples of AEX 12 and 13. However, identifying mineralogical phases by XRD in $<2 \mathrm{~mm}$ fractions soils is not so straightforward due to many practical problems. We fully matched only two mineralogical phases in all the soil samples which is quartz and potassium-Aluminum-Silicate. However, the full XRD peaks indicate that more minerals are also present, but due to heterogeneity of soils samples, it is difficult to find other minerals phases by only XRD peak of $<2 \mathrm{~mm}$ fractions. Therefore, to find more information about mineralogical phases, we performed XRF analysis that provides the elemental composition of minerals phase as oxide. XRF analysis indicated the presence of secondary minerals like illite and chlorite. The presence of high percentage Fe oxide not only indicated the iron mineral phase (goethite and ferrihydrite) but also indicated iron rich high charge smectite minerals (beidellite). The presence of iron rich smectite minerals in the Ganges sediments reported in several previous studies. Thus, we concluded that only XRD in $<2 \mathrm{~mm}$ fractions of soils is not adequate to identify the mineralogical phases of soil samples. Others analyses like XRF, XRD in $<2 \mu \mathrm{m}$ fractions will be necessary to locate an entire image of soil mineralogical phases.
\end{abstract}

\section{Keywords}

Soil Minerals, Ganges Floodplain Soil, X-Ray Diffraction (XRD), X-Ray Fluorescence Spectroscopy (XRF) 


\section{Introduction}

The commonest method for qualitative and quantitative mineral composition determination in soils is the X-Ray Diffraction (XRD). However, in natural multi-mineral systems, such as soils, it is difficult to carry out the identification and the quantitative analysis by X-ray diffraction patterns, mainly due to overlapping peaks [1]. Furthermore, the thickness of diffracting domains, particle size, particle-size distribution, and the sample weight or thickness in the holder, sample preparation, XRD instrument alignment, and data collection procedures may all contribute significantly to the problem [2]. Above all, the complexes of minor elements yield broad low-intensity XRD peaks, and these peaks often overlap with high-intensity peaks from silica, thereby making identification and quantitative determination difficult [3]. To overcome these limitations in XRD, researchers often use other techniques like XRF to get more information about soil minerals. X-ray Fluorescence Spectrometry (XRF) is a quick method for determining of the total elemental composition of soil samples. Unlike many laboratory techniques, XRF does not require any digestion techniques before the sample is analysed; therefore, it is a useful screening tool for determining the elements in soils. The determination of elements by XRF is providing the semi-quantitative information about soil mineral phases [3].

Soil minerals especially clay minerals are an important soil constituent that controls soil properties and influences its management and productivity. The most important property of clay minerals is their small size and large surface area. It also carries negative or positive charges on their external and internal surface. Clay minerals act as "Chemical Sponges" which hold water and dissolved plant nutrients weathered from other minerals. As the different types of minerals found in the soil weather, they change a soils ability to hold water and nutrients as well as changing their composition and nature due to physiographic change [6] [7] [8].

Bangladesh has a wide range of soils developed in parent materials ranging from recent alluvial deposits to sedimentary rocks of tertiary formation [4]. Under the influence of varied topographical condition and subsequent drainage patterns, the mineralogical composition of soils is also varied widely. A comprehensive study on mineralogical properties of soils developed under different parent materials not only provides information for family level classification but also is indispensable for assessment of its inherent potentiality and better management practices. "Ganges river alluvium" is the parent material which covers an area of around 796,751 ha area in lower Ganges river floodplain and $1,706,573$ ha area in Ganges Tidal floodplain of Bangladesh [5]. Both calcareous and non-calcareous floodplain soils are common in these regions and very important from agricultural purpose. The properties of soils of an area vary greatly with the content and properties of clay minerals. Moreover, the availability of soil nutrients depends significantly on clay minerals persisting in the respective soils of the concerned area. From this point of view, determination of clay minerals along with their quantification in the soils of Ganges Floodplain has been 
investigated for detailed characterization.

Considering studies of mineralogical phase analysis and their quantification using XRD and XRF data for Bangladeshi soils, there are limited studies reported Moslehuddin and Egashira [6]; Moslehuddin and Egashira [7] and Moslehuddin et al. [8]. However, more study may be required to understand the comprehensiveness of this. Ganges River Floodplain which divided into two regions; 1) Ganges Meander Floodplain and 2) Ganges Tidal Floodplain is an important agricultural region in Bangladesh. The region has many limitations like low soil fertility, salinity, acidity and calcareousness. To overcome these problems, soil mineralogical study is very important to identify mineralogy of all the soil series in Ganges River Floodplain region and provide more information for soil management as well as for sustainable agriculture. Minerals are indicator of the extent of weathering that has taken place, and control the inherent potentiality and crop production. The inherent potentiality can be estimated from the particle size distribution (clay content) and the nature and amounts of minerals in clay fraction [9]. Therefore, the objective of the study was to identify the clay minerals phases in lower Ganges River Floodplain and Ganges Tidal Floodplain soils.

\section{Materials and Methods}

\subsection{Materials}

The experiment was carried out in the pedology laboratory of the Soil Science Discipline, Khulna University along with BCSIR to find out the clay mineralogical composition of Low Ganges River Floodplain and Ganges Tidal Floodplain soils that covered AEZ 12 and AEZ 13. This chapter will provide a brief description of the materials and methods used in the study.

\subsubsection{Soils Sample Collection and Preparation}

Major soil series of the AEZ under study were identified from the semi-detailed soil survey reports of different Upazilas covering the area. In AEZ 12, considering the extent of occurrences soil samples were collected from four soil series whereas in AEZ 13 four soil samples were collected from three soil series. Thus, eight soil samples in total were collected from the $0-15 \mathrm{~cm}$ depth during Rabi season (October-March) based on the monsoon. General features of these soils are presented in Table 1. The soil samples were dried at room temperature, crushed, mixed thoroughly, sieved with a $2-\mathrm{mm}$ sieve and preserved in plastic bags for subsequent laboratory analyses.

\subsection{Methods}

Different physical and chemical parameters of soils like particle size analysis, soil $\mathrm{pH}$, electrical conductivity (EC), cation exchange capacity (CEC), and free carbonate were analyzed by following procedure.

\subsubsection{Physical Properties of Soils}

\section{1) Particle size analysis}

The particle size analysis of the soils was done by combination of sieving and 
Table 1. General Information of sampling sites.

\begin{tabular}{|c|c|c|c|c|c|c|}
\hline Physiography & Soil series & Land type & Location & Latitude and Longitude & Parant Material & Effervescence \\
\hline \multirow{4}{*}{$\begin{array}{l}\text { Low Ganges River } \\
\text { Floodplain }\end{array}$} & Raina & $\begin{array}{l}\text { Medium high } \\
\text { land }\end{array}$ & $\begin{array}{c}\text { Vill + Union: Char Harirampur } \\
\text { Thana: Charvadrasan } \\
\text { Districts: Faridpur }\end{array}$ & $\begin{array}{l}\mathrm{N}: 23^{\circ} 34.32^{\prime} \\
\mathrm{E}: 89^{\circ} 46.588^{\prime}\end{array}$ & $\begin{array}{l}\text { Ganges river } \\
\text { alluvium }\end{array}$ & Calcareous \\
\hline & Sara & High land & $\begin{array}{l}\text { Village: Charamrapur } \\
\text { Union: Hazigang } \\
\text { Thana: Charvadrasan } \\
\text { Districts: Faridpur }\end{array}$ & $\begin{array}{l}\text { N: } 23^{\circ} 34.203^{\prime} \\
\text { E: } 89^{\circ} 55.584^{\prime}\end{array}$ & $\begin{array}{l}\text { Ganges river } \\
\text { alluvium }\end{array}$ & Calcareous \\
\hline & Gopalpur & $\begin{array}{l}\text { Medium high } \\
\text { land }\end{array}$ & $\begin{array}{l}\text { Village: West gangabodi } \\
\text { Union: Krishna Nagar } \\
\text { Thana: Sador } \\
\text { Districts: Faridpur }\end{array}$ & $\begin{array}{l}\mathrm{N}: 23^{\circ} 34.79^{\prime} \\
\text { E: } 89^{\circ} 55.584^{\prime}\end{array}$ & $\begin{array}{l}\text { Ganges river } \\
\text { alluvium }\end{array}$ & Calcareous \\
\hline & Iswardi & $\begin{array}{l}\text { Medium } \\
\text { Low Land }\end{array}$ & $\begin{array}{l}\text { Village: West gangabodi } \\
\text { Union: Krishna Nagar } \\
\text { Thana: Sador } \\
\text { Districts: Faridpur }\end{array}$ & $\begin{array}{l}N: 23^{\circ} 34.90^{\prime} \\
E: 89^{\circ} 46.575^{\prime}\end{array}$ & $\begin{array}{l}\text { Ganges river } \\
\text { alluvium }\end{array}$ & Calcareous \\
\hline \multirow{4}{*}{$\begin{array}{l}\text { Ganges Tidal } \\
\text { Floodplain }\end{array}$} & Bajoa & $\begin{array}{l}\text { Medium high } \\
\text { land }\end{array}$ & $\begin{array}{l}\text { Village: Jelerdanga } \\
\text { Union: Ghutudia } \\
\text { Thana: Dumuria } \\
\text { Districts: Khulna }\end{array}$ & $\begin{array}{l}\mathrm{N}: 22^{\circ} 47.657^{\prime} \\
\mathrm{E}: 89^{\circ} 27.501^{\prime}\end{array}$ & $\begin{array}{l}\text { Ganges river } \\
\text { alluvium }\end{array}$ & Calcareous \\
\hline & Dacope & $\begin{array}{l}\text { Medium low } \\
\text { land }\end{array}$ & $\begin{array}{l}\text { Vill + Union: Ghutudia } \\
\text { Thana: Dumuria } \\
\text { Districts: Khulna }\end{array}$ & $\begin{array}{l}\text { N: } 22^{\circ} 47.697^{\prime} \\
\text { E: } 89^{\circ} 26.677^{\prime}\end{array}$ & $\begin{array}{l}\text { Ganges river } \\
\text { alluvium }\end{array}$ & Calcareous \\
\hline & Bajoa & $\begin{array}{l}\text { Medium high } \\
\text { land }\end{array}$ & $\begin{array}{c}\text { Salinity Research center } \\
\text { Batiaghata, Khulna }\end{array}$ & $\begin{array}{l}\text { N: } 22^{\circ} 41.785^{\prime} \\
\text { E: } 089^{\circ} 31.626^{\prime}\end{array}$ & $\begin{array}{l}\text { Ganges river } \\
\text { alluvium }\end{array}$ & Calcareous \\
\hline & Dumuria & $\begin{array}{l}\text { Medium low } \\
\text { land }\end{array}$ & $\begin{array}{l}\text { Vill + Union: Ghutudia } \\
\text { Thana: Dumuria } \\
\text { Districts: Khulna }\end{array}$ & $\begin{array}{l}\text { N: } 22^{\circ} 47.929^{\prime} \\
\text { E: } 089^{\circ} 26.769^{\prime}\end{array}$ & $\begin{array}{l}\text { Ganges river } \\
\text { alluvium }\end{array}$ & Calcareous \\
\hline
\end{tabular}

(Source: Soil and land resource utilization guide, SRDI, 2008; 1989 and 1990).

hydrometer method as described by Gee and Bauder [10]. Textural classes were determined using Marshall's Triangular Coordinate systems. General information of sampling sites was shown in Table 1.

\subsubsection{Chemical Properties of Soils}

The EC was measured at a soil: water ratio of 1:5 with the help of EC meter and converted into 1:1 ratio as suggested by USDA [11]. Soil $\mathrm{pH}$ was determined electrochemically at soil: water ratio of 1:2.5 with the help of glass electrode $\mathrm{pH}$ meter as suggested by Jackson [12]. The CEC of the soils were determined by extracting the soil with $1 \mathrm{~N} \mathrm{KCl} \mathrm{(} \mathrm{pH} 7.0)$ followed by the replacing the potassium in the exchange complex by $1 \mathrm{~N} \mathrm{NH}_{4} \mathrm{OAc}$. The displaced potassium was determined by a flame analyzer at $589 \mathrm{~nm}$ respectively [13].

\subsubsection{Separation of Clay Fraction}

At first, the soils were treated with $1 \mathrm{M} \mathrm{NaCH}_{3} \mathrm{COO}$ ( $\mathrm{pH}$ 5.0) in order to remove $\mathrm{CaCO}_{3}$ as the soils were derived from calcareous Ganges alluvium. For this $10 \mathrm{~g}$ of air dried soil was weighed and placed into a 50- $\mathrm{ml}$ centrifugal tube, with the 
ratio of (soil: $1 \mathrm{M} \mathrm{NaCH}_{3} \mathrm{COO}$ : water $=5 \mathrm{~g}: 5 \mathrm{ml}: 50 \mathrm{ml}$ ) and centrifuged for 10 min at $1500 \mathrm{rpm}$ followed by decantation of the supernatant [10]. Then the soil was taken into $500 \mathrm{ml}$ biker. About $100 \mathrm{ml}$ of $7 \% \mathrm{H}_{2} \mathrm{O}_{2}$ was added and allowed to stand for about 10 minutes until frothing was ceased. After removing the organic matter, the biker was cooled and added $100 \mathrm{ml}$ calgon. Then the content was transferred to a dispersion cup and stirred for $1 \mathrm{~min}$ with the help of an electrical stirrer. The $\mathrm{pH}$ of the suspension was adjusted to 10 by addition of $1 \mathrm{M} \mathrm{NaOH}$. The soil suspension then was transferred into a $1 \mathrm{~L}$ sedimentation cylinder was added up to the mark. Time and temperature were recorded. The cylinder was shaken for 1 minute and allowed to stand for an appropriate time. After standing for an appropriate time, the $<2$ um clay fraction was simphoned out into a plastic beaker and added $0.1 \mathrm{M} \mathrm{NaCl}$ in order to flocculate the clay fraction.

\subsubsection{Mineralogical Phase Analysis by XRD}

1 gm clay sample of each soil was taken in a sample holder of XRD machine for finding the X-ray patterns. XRD pattern were obtained using a D8 Advance (Bruker) X-ray diffractometer with $\mathrm{Cu} \mathrm{Ka}$ radiation at $40 \mathrm{kV}$ and $40 \mathrm{~mA}$ and at a scanning speed of $2^{\circ} 2 \theta \mathrm{min}^{-1}$ over a range of $\left(0^{\circ}\right.$ to $\left.90^{\circ}\right) 2 \theta$. Then picks were processed for the mineralogical phase by "Eva" software. The mineralogical phases were identified with the software by comparing the picks of pure minerals.

\subsubsection{Compositional Phase Analysis by XRF}

The XRF instruments used in this work were obtained from Thermo Scientific NITON UK. Two instruments were used: the XLp 703 Cd-109 source analyzer and the XLt 793 miniaturized X-ray tube for thin sample and bulk (soil) sample analysis. In both cases, operation involves a simple "point and shoot" technique. Prior to sample analysis, an internal instrument calibration was performed. All samples were analyzed using the bulk mode for soil sample. Each sample was analyzed for $45 \mathrm{~s}$ per sample. During the XRF trial, soil samples were analyzed through a freezer bag. An empty freezer bag was analyzed as a blank sample and all sample measurements were blank-corrected.

\section{Results and Discussion}

\section{1. pH, EC, CEC and Carbonate Content}

Some selected properties of the soils are shown in Table 2. The soils of the Lower Ganges River Floodplain and Ganges Tidal Floodplain were found to be slightly alkaline in nature having the $\mathrm{pH}$ values ranging between 7.35 and 7.9. The EC ranged from 0.78 to $3.80 \mathrm{dS} \cdot \mathrm{m}^{-1}$, indicating slightly saline nature of the soils at Lower Ganges River Floodplain whereas moderate to saline soils having the EC values ranging between 5.07 to $14.57 \mathrm{dS} \cdot \mathrm{m}^{-1}$ were found in Ganges Tidal Floodplain. The CEC was in a range from 15.4 to $20.7 \mathrm{cmol} \cdot(+) \cdot \mathrm{kg}^{-1}$ in all the studied soils and was found to be in the high categories according to the Bangladesh soil standard [18]. The percentage of free carbonate with a range of 19.6 
Table 2. pH, EC, CEC and Free Carbonate contents in soil sample.

\begin{tabular}{cccccc}
\hline AEZ & Soil Series & $\mathrm{pH}$ & $\begin{array}{c}\text { EC } \\
(\mathrm{dS} / \mathrm{m})\end{array}$ & $\begin{array}{c}\text { CEC } \\
(\mathbf{1 : 1}) \text { ratio }\end{array}$ & $\begin{array}{c}\text { Free Carbonate } \\
(\mathrm{g} / \mathrm{kg})\end{array}$ \\
\hline & Raina & 7.86 & 1.45 & 18.17 & 68.6 \\
Lower Ganges & Sara & 7.84 & 0.78 & 15.4 & 19.6 \\
River Floodplain & Gopalpur & 7.90 & 1.45 & 17.1 & 36.7 \\
& Iswardi & 7.35 & 3.80 & 19.52 & 31.8 \\
& Bajoa & 7.57 & 14.57 & 20.7 & 34.3 \\
Ganges Tidal & Dacope & 7.80 & 5.7 & 16.4 & 19.6 \\
Floodplain & Bajoa & 7.49 & 6.34 & 20.3 & 22.1 \\
& Dumuria & 7.72 & 5.07 & 19.8 & 24.5 \\
\hline
\end{tabular}

to $68.6 \mathrm{~g} \cdot \mathrm{kg}^{-1}$ in all the studied soils of Lower Ganges River Floodplain and Ganges Tidal Floodplain indicating calcareous nature of the soils.

\subsection{Particle Size Distribution}

Particle size distribution and textural classes of soils have been presented in $\mathrm{Ta}$ ble 3. In Lower Ganges River Floodplain, the clay $(<2 \mu \mathrm{m})$ content varied from $22.2 \%$ to $40.01 \%$ depending on the land types. The soils collected from high land and medium high land had lower clay content than those collected from lowland and very lowland. The possible reason behind this is loss of finer particles such as clay particles from the upper elevation through surface runoff to the lower elevation. The texture of Sara, Raina, Goplapur and Iswardi soil series were loam, silty loam, clay loam and Silty clay respectively. Distinct variation in the clay content was observed between soil series at Lower Ganges River Floodplain. The Iswardi series had the highest clay content $(40.01 \%)$ followed by the Goplapur and Raina series (34.7\% and 27.2\%), and the lowest content was observed in the Sara series (22.2\%).

On the other hand, the soil series of Ganges Tidal Floodplain characterized by higher contents of clay particles (35.95\% to $40.45 \%$ ). The higher clay content was mostly related to the position of soils on lower topography. Bajoa soils showed silty clay loam texture, while Dacope and Dumuria soils were identified as silty clay texture.

\subsection{Mineralogical Phase Analysis}

\subsubsection{Lower Ganges River Floodplain Soils}

The XRD patterns of the $<2 \mu \mathrm{m}$ clay fraction of the Raina, Sara, Gopalpur and Iswardi soils are presented in Figures 1-4 respectively.

The XRD patterns indicated that all the soils have generally same mineralogical phases. Peaks are generally broad, indicating lower crystallinity and/or small crystallite size of the minerals. The poorly defined diffraction effect between 0 to 18, 2-Theta-Scale indicated the complex nature of soil minerals. The minerals 
Table 3. Particle-size distribution in soil.

\begin{tabular}{cccccc}
\hline \multirow{2}{*}{ Soil Series } & Land Type & \multicolumn{3}{c}{ Particle size distribution \% } & \multirow{2}{*}{$\begin{array}{c}\text { Texture } \\
\text { (USDA) }\end{array}$} \\
\cline { 3 - 5 } & & Sand & Silt & Clay & Silty Loam \\
\hline Raina & MHL & 17.8 & 55 & 27.2 & Loam \\
Sara & HL & 35.3 & 42.5 & 22.2 & Clay Loam \\
Gopalpur & MHL & 21.05 & 41.25 & 34.7 & Silty Clay \\
Iswardi & MLL & 18.53 & 41.37 & 40.01 & Silty clay Loam \\
Bajoa & MHL & 7.05 & 57 & 35.95 & Silty clay \\
Dacope & MLL & 12.05 & 47.5 & 40.45 & Silty clay Loam \\
Bajoa & MHL & 9.55 & 52.5 & 37.95 & Silty clay \\
Dumuria & MLL & 14.55 & 45 & 40.45 &
\end{tabular}

$\mathrm{HL}=$ High Land $; \mathrm{MHL}=$ Medium High Land; $\mathrm{MLL}=$ Medium Low Land $; \mathrm{LL}=$ Low Land.

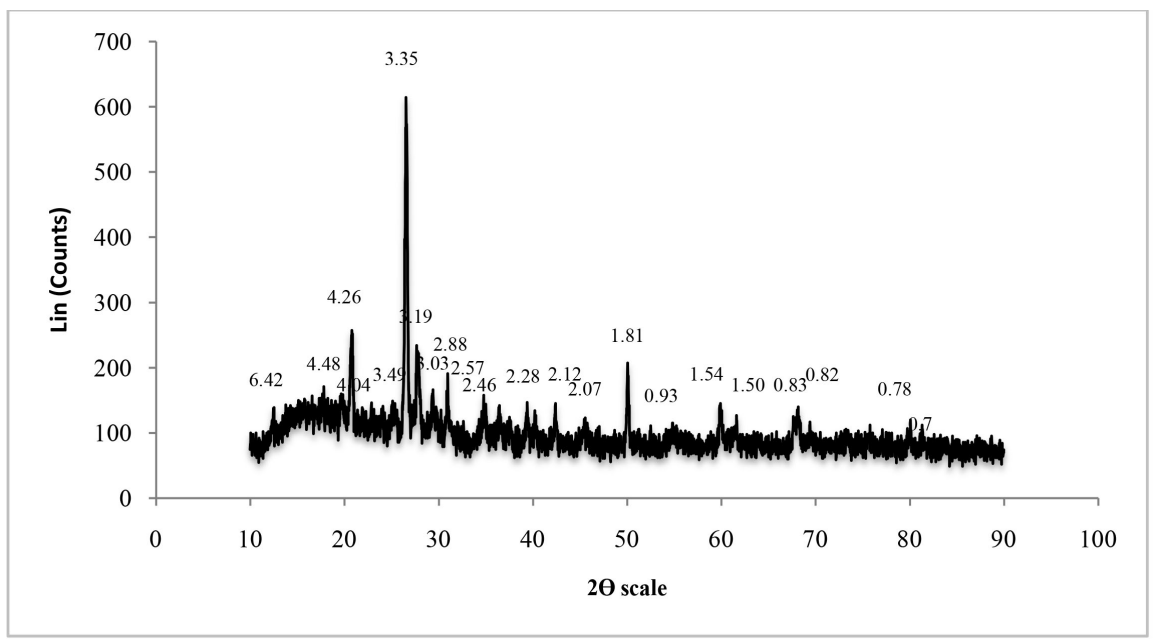

Figure 1. X-Ray diffraction peak of Raina series.

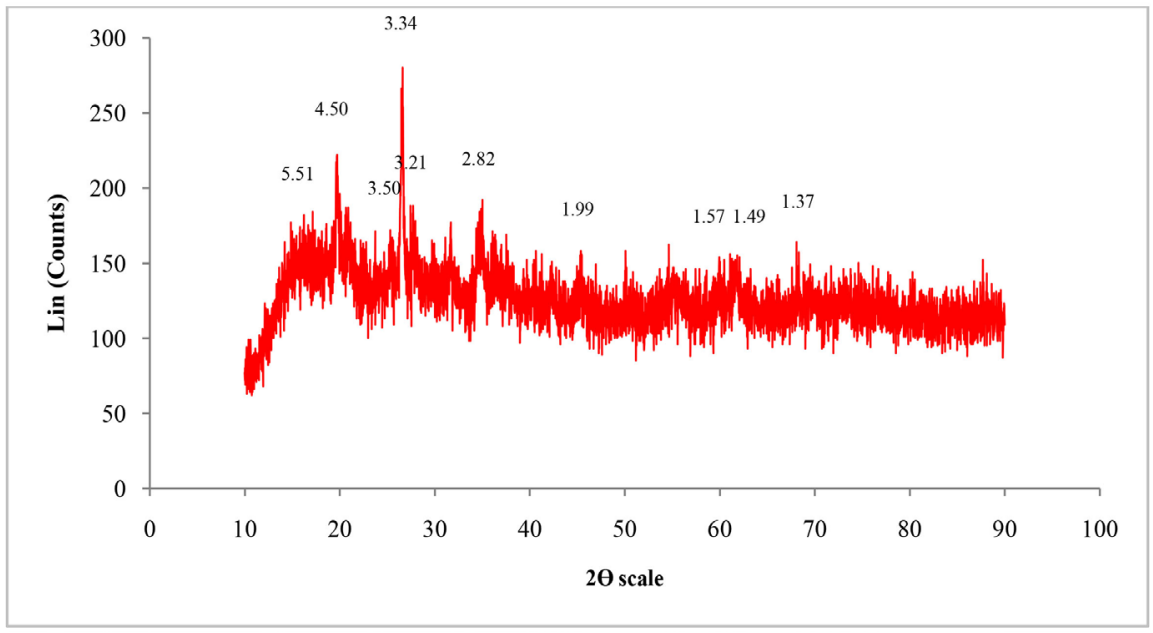

Figure 2. X-Ray diffraction peak of Sara series. 


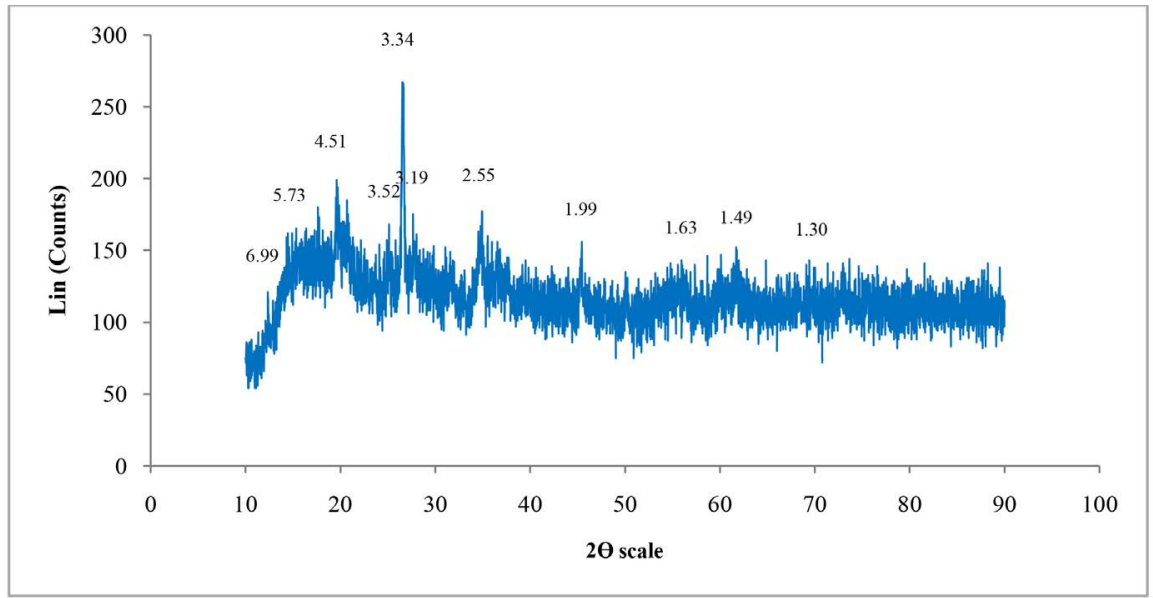

Figure 3. X-Ray diffraction peak of Gopalpur series.

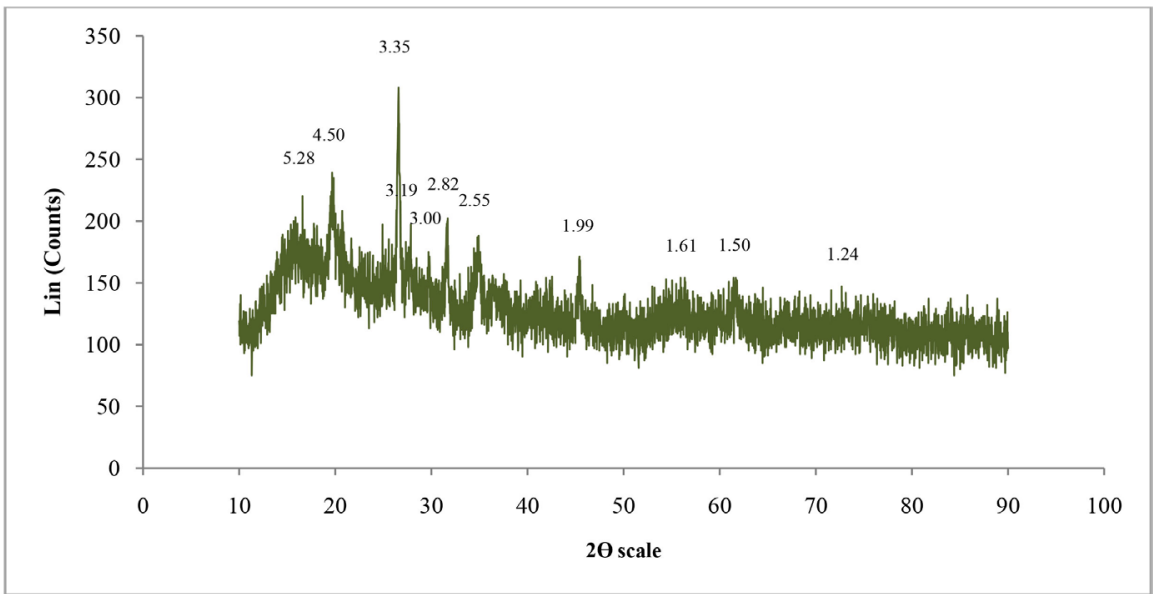

Figure 4. X-Ray diffraction peak of Iswardi series.

could be frequently transformed. Thus, single mineral discrete phase with characterized peak was not detected. However, some characterized peaks were observed which indicated the type of minerals present in the soil samples. All the soil samples in Lower Ganges River Floodplain have a board peak at 4.5 and 2.56 $\AA$ indicated the presence of mica and smectite minerals. The peak at $3.35 \AA$ also indicated the presence of mica minerals. However, the discrete phase of mica, chlorite, kaolinite and smectite at 10.00, 14.00, 7.00 and $12.00 \AA$, respectively was missing. The reasons of missing or very low intensity peaks could be strong texture in the sample or because of symmetry of crystal structure. Disordered kaolinite was detected with the peak at $4.48 \AA$, 3.35 and $2.56 \AA$, respectively. The peak at 4.26 along with $3.35 \AA$ showed the presence of quartz. The reflections of 3.19 and $3.00 \AA$ were used for identification of Na-feldspar and calcite, respectively. The presence of vermiculite was ascertained by the peak intensity of the $2.82 \AA$ reflections. Disordered chlorite was ascertained by the peak intensity of $2.56 \AA$ reflections but it was not identified as a discrete phase in the present study. Indicated the presence of inter stratified minerals. 


\subsubsection{Ganges Tidal Floodplain Soils}

The XRD patterns of the $<2 \mu \mathrm{m}$ clay fraction of the Bajoa, Dacope, Bajoa and Dumuria soils are presented in Figures 5-8 respectively.

All the soils have generally same mineralogical phases indicating from the XRD pattern. Peaks are generally broad, indicating lower crystallinity and /or small crystallite size of the minerals. The poorly defined diffraction effect between 0 to 18, 2-Theta-Scale indicated the complex nature of soil minerals. The minerals could be frequently transformed. Thus, single mineral discrete phase with characterized peak was not detected. However, some characterized peaks were observed which indicated the type of minerals present in the soil samples. All the soil samples in Lower Ganges River Floodplain have a board peak at 4.5 and $2.56 \AA$ indicated the presence of mica and smectite minerals. The presence of $14.20 \AA$, $10.36 \AA$ and $7.11 \AA$ peaks also indicated smectite or chlorite, mica or illite and kaolinite minerals respectively. Disordered kaolinite was detected with the peak at $4.48 \AA, 3.35$ and $2.56 \AA$, respectively. The peak at 4.26 along with 3.35 $\AA$ showed the presence of quartz. The reflections of 3.19 and $3.00 \AA$ were used for identification of $\mathrm{Na}$-feldspar and calcite, respectively. The presence of vermiculite was ascertained by the peak intensity of the $2.82 \AA$ reflections. Disordered chlorite was ascertained by the peak intensity of $2.56 \AA$ reflections but it was not identified as a discrete phase in the present study. However, some characterized peaks were observed which indicated the type of minerals present in the soil sample.

\subsection{XRF Analysis}

Knowledge of the chemical composition of soil samples $(<2 \mu \mathrm{m})$ is necessary for clarifying the likely source regions and is important for weathering phenomena [19]. Chemical analysis of soil samples provides valuable information about potentially harmful trace elements such as heavy metals $(\mathrm{Cu}, \mathrm{Ni}$, and $\mathrm{Zn})$. On the other hand, the major-element and ion-chemistry analyses provide estimates of mineral components. The chemical analysis of soil samples was performed via $\mathrm{XRF}$ analysis for the major oxides are presented in Tables 4-6, respectively.

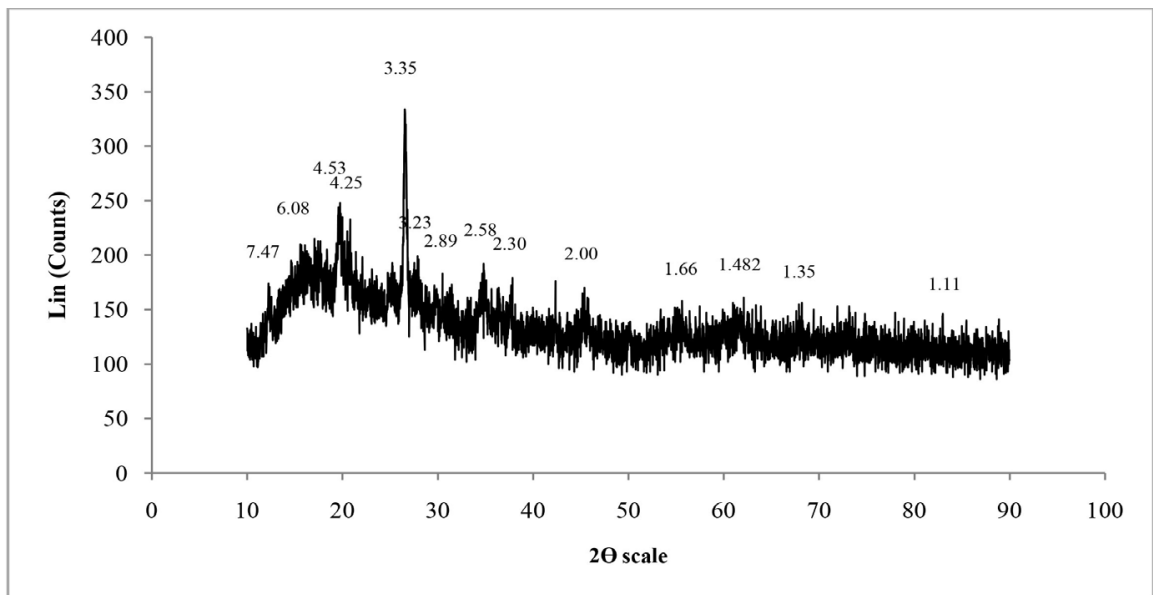

Figure 5. X-Ray peak of Bajoa series. 


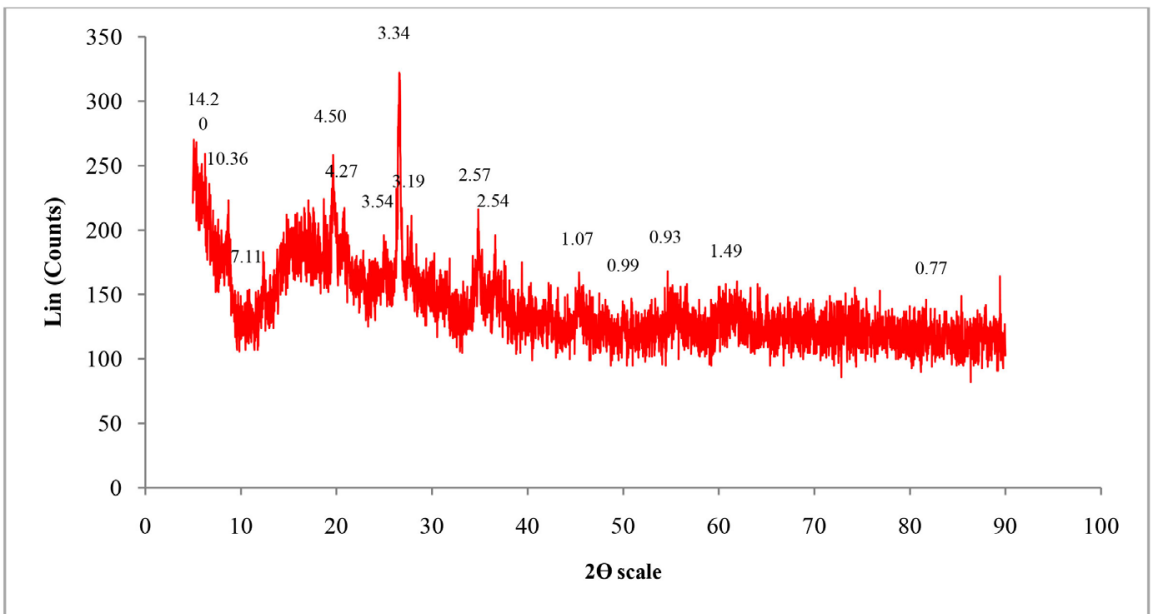

Figure 6. X-Ray peak of Dacope series.

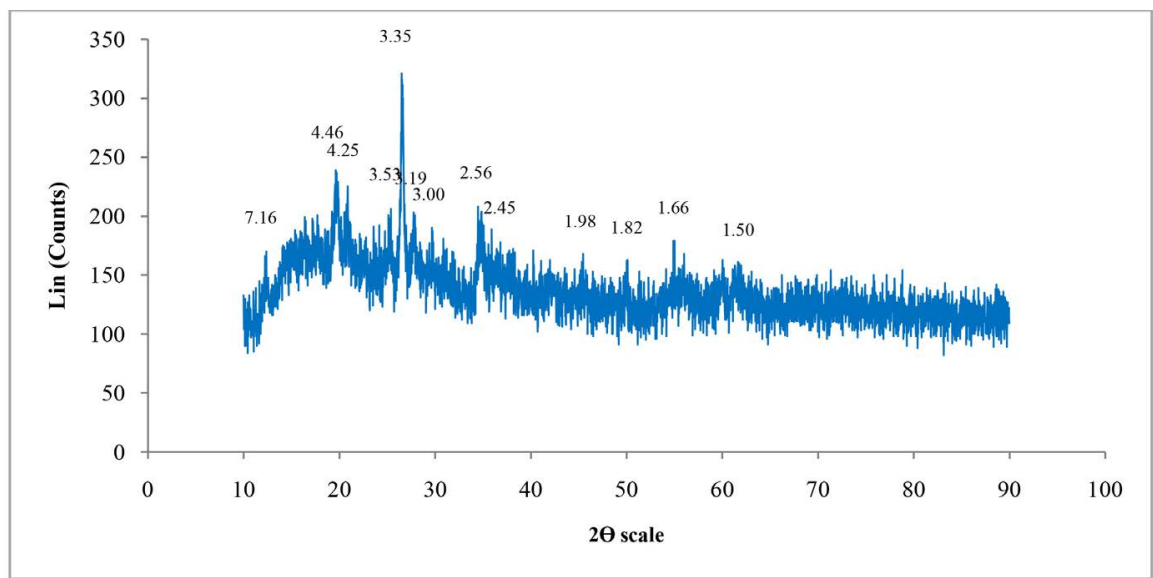

Figure 7. X-Ray peak of Bajoa series.

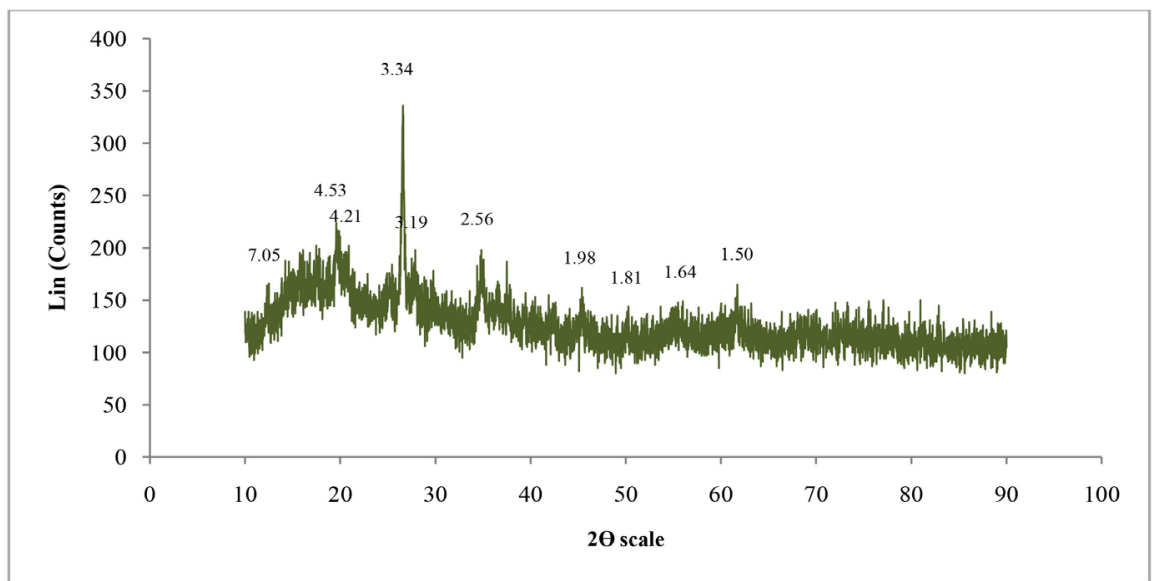

Figure 8. X-Ray peak of Dumuria series.

In general, the analysis reveals that all samples contain major amounts of $\mathrm{SiO}_{2}$ as well as substantial $\mathrm{Al}_{2} \mathrm{O}_{3}$ concentrations. More specifically, average major elements of all the soil samples indicate a predominant $\mathrm{SiO}_{2}$ mass component 
Table 4. XRF results of bajoa series.

\begin{tabular}{ccllll}
\hline Analyte & Result (\%) & Proc-Calc & Line & Net Int. & BG Int. \\
\hline $\mathrm{SiO}_{2}$ & 54.4311 & Quant.-FP & $\mathrm{SiKa}$ & 73.029 & 0.214 \\
$\mathrm{Al}_{2} \mathrm{O}_{3}$ & 15.9267 & Quant.-FP & $\mathrm{AlKa}$ & 44.701 & 1.745 \\
$\mathrm{Fe}_{2} \mathrm{O}_{3}$ & 13.4059 & Quant.-FP & $\mathrm{FeKa}$ & 62.431 & 0.152 \\
$\mathrm{P}_{2} \mathrm{O}_{5}$ & 7.4676 & Quant.-FP & $\mathrm{P} \mathrm{Ka}$ & 14.296 & 0.234 \\
$\mathrm{~K}_{2} \mathrm{O}$ & 5.2542 & Quant.-FP & $\mathrm{K} \mathrm{Ka}$ & 24.170 & 0.241 \\
$\mathrm{CaO}$ & 1.6796 & Quant.-FP & $\mathrm{CaKa}$ & 5.830 & 0.138 \\
$\mathrm{TiO}_{2}$ & 1.4392 & Quant.-FP & TiKa & 1.217 & 0.026 \\
$\mathrm{MnO}^{2}$ & 0.1218 & Quant.-FP & $\mathrm{MnKa}$ & 0.508 & 0.096 \\
$\mathrm{SO}_{3}$ & 0.1046 & Quant.-FP & $\mathrm{S} \mathrm{Ka}$ & 0.125 & 0.061 \\
$\mathrm{Cr}_{2} \mathrm{O}_{3}$ & 0.0609 & Quant.-FP & $\mathrm{CrKa}$ & 0.163 & 0.059 \\
$\mathrm{ZnO}$ & 0.0347 & Quant.-FP & $\mathrm{ZnKa}$ & 0.267 & 0.144 \\
$\mathrm{ZrO}_{2}$ & 0.0297 & Quant.-FP & $\mathrm{ZrKa}$ & 0.602 & 0.750 \\
$\mathrm{NiO}$ & 0.0223 & Quant.-FP & NiKa & 0.135 & 0.094 \\
$\mathrm{CuO}$ & 0.0218 & Quant.-FP & $\mathrm{CuKa}$ & 0.158 & 0.116
\end{tabular}

Table 5. XRF results of gopalpur series.

\begin{tabular}{ccclcc}
\hline Analyte & Result (\%) & Proc-Calc & Line & Net Int. & BG Int. \\
\hline $\mathrm{SiO}_{2}$ & 54.2834 & Quant.-FP & SiKa & 71.613 & 0.222 \\
$\mathrm{Al}_{2} \mathrm{O}_{3}$ & 15.2483 & Quant.-FP & $\mathrm{AlKa}$ & 41.752 & 1.689 \\
$\mathrm{Fe}_{2} \mathrm{O}_{3}$ & 13.8933 & Quant.-FP & $\mathrm{FeKa}$ & 63.087 & 0.155 \\
$\mathrm{P}_{2} \mathrm{O}_{5}$ & 7.8149 & Quant.-FP & $\mathrm{P} \mathrm{Ka}$ & 14.702 & 0.222 \\
$\mathrm{~K}_{2} \mathrm{O}$ & 4.7744 & Quant.-FP & $\mathrm{K} \mathrm{Ka}$ & 21.568 & 0.217 \\
$\mathrm{CaO}$ & 2.3710 & Quant.-FP & $\mathrm{CaKa}$ & 8.155 & 0.141 \\
$\mathrm{TiO}_{2}$ & 1.4392 & Quant.-FP & TiKa & 1.188 & 0.024 \\
$\mathrm{SO}_{3}$ & 0.0773 & Quant.FP & $\mathrm{S} \mathrm{Ka}$ & 0.090 & 0.060 \\
$\mathrm{ZnO}$ & 0.0440 & Quant.-FP & $\mathrm{ZnKa}$ & 0.328 & 0.135 \\
$\mathrm{ZrO}_{2}$ & 0.0281 & Quant.-FP & $\mathrm{ZrKa}$ & 0.552 & 0.714 \\
$\mathrm{NiO}$ & 0.0261 & Quant.-FP & NiKa & 0.153 & 0.086 \\
\hline
\end{tabular}

$\left(54.4 \%\right.$ - 49.2\%) with significant $\mathrm{Al}_{2} \mathrm{O}_{3}(14.7 \%$ - $13.9 \%), \mathrm{Fe}_{2} \mathrm{O}_{3}(13.89 \%$ $13.41 \%)$, and $\mathrm{P}_{2} \mathrm{O}_{5}(11.41 \%-7.47 \%)$ contributions; a few percent of $\mathrm{K}_{2} \mathrm{O}(5.25 \%$ - 4.77\%), $\mathrm{CaO}(4.46 \%-1.68 \%)$ and $\mathrm{TiO}_{2}(1.44 \%-1.36 \%)$, as well as trace amounts $(<1 \%)$ of $\mathrm{SO}_{3}, \mathrm{Cr}_{2} \mathrm{O}_{3}, \mathrm{ZrO}_{2}, \mathrm{ZnO}, \mathrm{CuO}$ and $\mathrm{NiO}$.

\subsection{Discussion}

The soils of the Low Ganges river floodplain and Ganges Tidal Floodplain were medium textured, having considerable amounts of clay varying mainly with the land types. Higher amounts of clay were found in soils situated on lowland and 
Table 6. XRF results of raina series.

\begin{tabular}{ccllll}
\hline Analyte & Result (\%) & Proc-Calc & Line & Net Int. & BG Int. \\
\hline $\mathrm{SiO}_{2}$ & 49.2479 & Quant.-FP & $\mathrm{SiKa}$ & 60.811 & 0.202 \\
$\mathrm{Al}_{2} \mathrm{O}_{3}$ & 14.6828 & Quant.-FP & $\mathrm{AlKa}$ & 37.172 & 1.466 \\
$\mathrm{Fe}_{2} \mathrm{O}_{3}$ & 13.7203 & Quant.-FP & FeKa & 55.759 & 0.153 \\
$\mathrm{P}_{2} \mathrm{O}_{5}$ & 11.4124 & Quant.-FP & $\mathrm{P} \mathrm{Ka}$ & 20.761 & 0.298 \\
$\mathrm{~K}_{2} \mathrm{O}$ & 4.8013 & Quant.-FP & $\mathrm{K} \mathrm{Ka}$ & 20.311 & 0.221 \\
$\mathrm{CaO}$ & 4.4605 & Quant.-FP & $\mathrm{CaKa}$ & 14.263 & 0.170 \\
$\mathrm{TiO}_{2}$ & 1.3604 & Quant.-FP & TiKa & 0.999 & 0.021 \\
$\mathrm{SO}_{3 \text { gypsum }}$ & 0.0987 & Quant.-FP & $\mathrm{S} \mathrm{Ka}$ & 0.109 & 0.064 \\
$\mathrm{Cr}_{2} \mathrm{O}_{3}$ & 0.0663 & Quant.-FP & $\mathrm{CrKa}$ & 0.154 & 0.058 \\
$\mathrm{ZrO}$ & 0.0523 & Quant.-FP & $\mathrm{ZrKa}$ & 0.932 & 0.745 \\
$\mathrm{ZnO}$ & 0.0469 & Quant.-FP & $\mathrm{ZnKa}$ & 0.318 & 0.146 \\
$\mathrm{CuO}$ & 0.0265 & Quant.-FP & $\mathrm{CuKa}$ & 0.169 & 0.123 \\
$\mathrm{NiO}$ & 0.0239 & Quant.-FP & NiKa & 0.127 & 0.099 \\
\hline
\end{tabular}

very lowland than those on highland and medium highland. XRD patterns with Eva software indicated that the predominant mineral in the clay fraction was mica/illite followed by smectite in all soils; some chlorite, kaolinite and vermiculite were identified (Figure 9 and Figure 10). It seems that all soils of the present study are uniform in nature. The result of the present study clearly supports the clay mineralogy suite (mica/illite-smectite) of this agroecological region as proposed by Moslehuddin et al. [20].

On the other hand, most $\mathrm{Si}$ and $\mathrm{Al}$ oxides, found in the XRF, are in the illite and chlorite minerals, the remaining ones are in the Quartz (Tables 4-6). Basically, all Fe oxide composes the Goethite phase but here the higher percentage indicated that $\mathrm{Fe}$ oxide also contributed for smectite minerals because the smectite of the Ganges sediments is mainly iron rich, high-charge beidellite [7]. Surprisingly we did not find any $\mathrm{Na}$ an $\mathrm{Mg}$ oxide which is attributed to the presence of smectite minerals. Significant amounts of Ti oxide are present in Anatase and Rutile. The Ca oxide found in the clay fraction was attributed to the presence of calcite mineral. Likewise, The K oxide is contributed by illite minerals. Significant amounts of $\mathrm{P}$ oxide indicated the presence of apatite minerals but here it could be originated from phosphate fertilizer as XRD did not indicate the presence of apatite minerals in the soil samples. All these characteristics are common to soils in advanced weathering processes [21].

The Ganges river sediments are calcareous in nature and have considerable amounts of smectite in addition to mica. Consequently, the inherent potentially is high for the soils developed from these sediments [22] [23]. As characterized by Moslehuddin and Egashira [7], the smectite of the Ganges sediments is mainly iron rich, high-charge beidellite, and is considered to be less stable under the acidified condition and the alternate oxidation-reduction situation. Moslehuddin et al. [8] further reported the disappearing trend of the smectite in some 


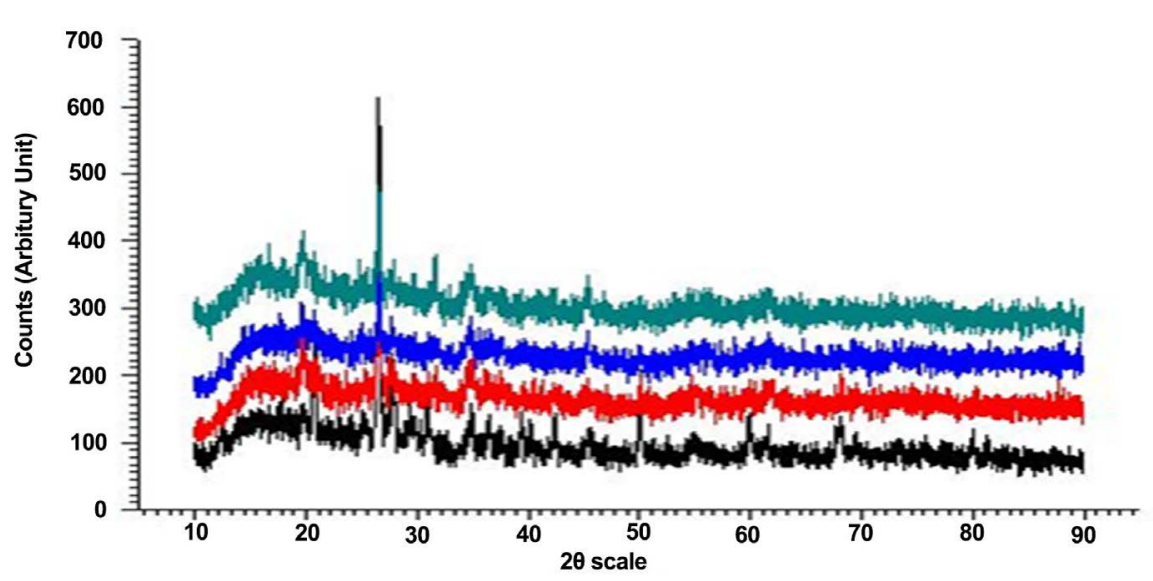

Figure 9. Compiled figure of XRD peaks on Raina, Sara, Gopalpur, Iswardi series.

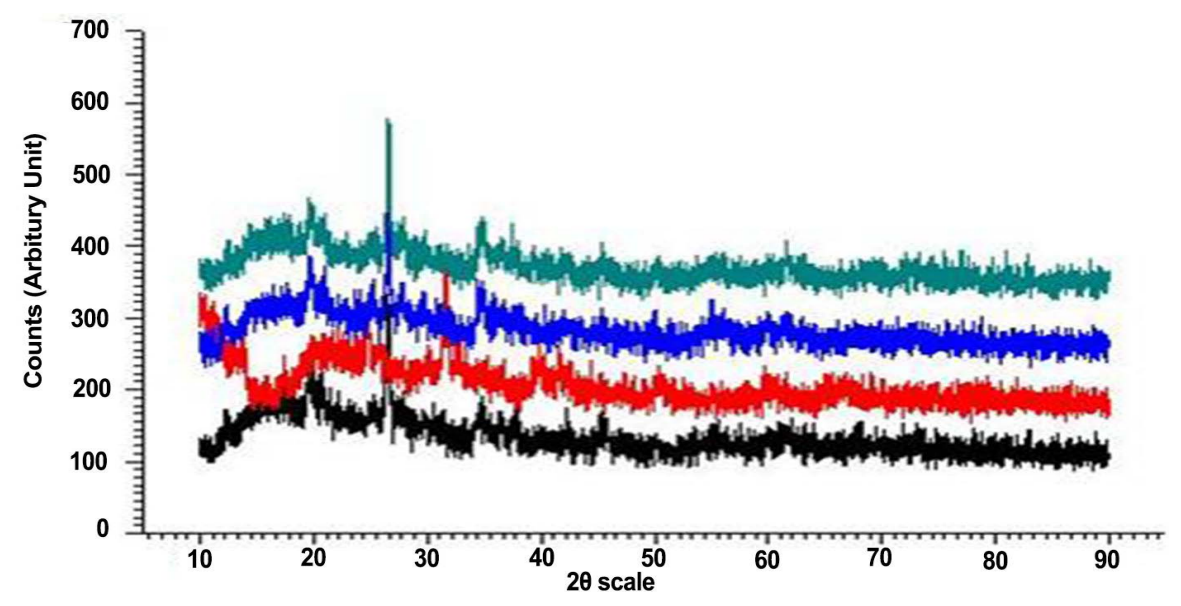

Figure 10. Compiled figure of XRD peaks on Bajoa, Dacope, Bajoa and Dumuria series.

decalcified soils of the High Ganges River Floodplain. However, the disappearing trend of the smectite is not clear in soils of Lower Ganges River Floodplain and Ganges Tidal Floodplain, which was reported in soils of the adjacent AEZ, High Ganges River Floodplain, by Moslehuddin and Egashira [6] and Moslehuddin et al. [8].

Clay content and its mineralogical composition determine the inherent potentially of soils. All the soils of the present study had medium to considerable amounts of clay, dominated by mica/illite and smectite minerals. Therefore, the inherent potentially of this region could be termed as "good". Good inherent potentially means the high buffer capacity and the high level of nutritional status of soils. These soils support good crop growth and high production.

\section{Conclusion}

To fully understand clay mineral characteristics, clay mineralogy by XRD and chemical composition by XRF were examined in the Lower Ganges River Floodplain and Gnages Tidal Floodplain by collecting soil samples from several locations. The results showed that illite, smectite and chlorite are the main minera- 
logical components of the soil samples, in descending order, over Lower Ganges River Floodplain and Ganges Tidal Floodplain, and were present in all the selected soil samples. In contrast, significantly lower percentages for calcite, geothite, gypsum, quartz, and anatase were found. On the other hand, $\mathrm{SiO}_{2}, \mathrm{Al}_{2} \mathrm{O}_{3}$, $\mathrm{Fe}_{2} \mathrm{O}_{3}, \mathrm{P}_{2} \mathrm{O}_{5}, \mathrm{~K}_{2} \mathrm{O} \mathrm{CaO}$ and $\mathrm{TiO}_{2}$ were the major elements characterizing the soils, while small amounts of $\mathrm{S}, \mathrm{Cr}, \mathrm{Zr}, \mathrm{Zn}, \mathrm{Ni}$ and $\mathrm{Cu}$ were also found as trace elements. The mineralogy and chemical composition of soil samples at both regions were nearly the same and quite similar to the soil samples collected at several locations. This suggests that the soil samples in Lower Ganges River Floodplain and Ganges Tidal Floodplain are similar parent materials, i.e. from the Ganges basin, and in a most cases can also be long-range transported to distant regions.

\section{Conflicts of Interest}

The authors declare no conflicts of interest regarding the publication of this paper.

\section{References}

[1] Bish, D.L. (1994) Quantitative X-Ray Diffraction Analysis of Soils. In: Amonette, J.E., Zelazny, L.W. and Luxmoore, R.J., Eds., Quantitative Methods in Soil Mineralogy, Soil Science Society of America, Madison, 267-295.

[2] Aparico, P. and Ferrell Jr., R.E. (2001) An application of Profile Fitting and CLAY++ for the Quantitative Representation (QR) of Mixed-Layer Clay Minerals. Clay Minerals, 36, 501-514.

[3] Singh, V. and Agrawal, H.M. (2012) Qualitative Soil Mineral Analysis by EDXRF, XRD and AAS Probes. Radiation Physics and Chemistry, 81, 1796-1803.

[4] Saheed, S.M. and Hussain, M.S. (1992) Wetland Soils of Bangladesh. In: Kimble, J.M., Ed., Characterization, Classification and Utilization of Wet Soils, USDA, Soil Conservation Service, National Soil Survey Centre, 220-229.

[5] Hussain, M.S. (1992) Soil Classification with Special Reference to the Soils of Bangladesh. University of Dhaka, Bangladesh.

[6] Moslehuddin, A.Z.M. and Egashira, K. (1996) Minerological Composition of Some Important Paddy Soils of Bangladesh. Journal of the Faculty of Agriculture, Kyushu University, 19, 33-54.

[7] Moslehuddin, A.Z.M. and Egashira, K. (1997) Characterization of Smectites Found in Ganges Floodplain Soils of Bangladesh. Clay Science, 10, 151-162.

[8] Moslehuddin, A.Z.M., Saheed, S.M. and Egashira, K. (1998) Disappearing Trend of Smectite in Ganges Floodplain Soils of Bangladesh. Clay Science, 10, 349-362.

[9] Kawaguchi, K. and Kyuma, K. (1977) Paddy Soil in Tropical Asia. The University Press of Hawaii, Honolulu.

[10] Gee, G.W. and Bauder, J.W. (1986) Particle Size Analysis. In: Klute, A., Ed., Methods of Soil Analysis, Part I, Physical and Mineralogical Methods, American Society of Agronomy, Madison, 383-411.

[11] USDA (2004) Soil Survey Laboratory Manual, Soil Survey Investigation Report No. 42, Version 4.0. USDA-NRCS, USA.

[12] Jackson, M.L. (1973) Soil Chemical Analysis. Prentice Hall of India Private Limited, 
New Delhi.

[13] Jackson, M.L. (1967) Soil Chemical Analysis. 2nd Edition, Prentice Hall of India Private Limited, New Delhi.

[14] Bennett, H. and Oliver, G. (1992) XRF Analysis of Ceramics. Minerals and Applied Materials. Jobn Wiley and Son, New York, 67-93.

[15] Watson, J.S. (1996) Fast, Simple Method of Powder Pellet Preparation for X-Ray Fluorescence Analysis. X-Ray Spectrometry, 25, 173-174. https://doi.org/10.1002/(SICI)1097-4539(199607)25:4<173::AID-XRS158>3.0.CO;2$\underline{Z}$

[16] Lupon, D.F., Merker, J. and Scholz, F. (1997) The Correct Use of Platinum in the XRF Laboratory. X-Ray Spectrometry, 26, 132-140. https://doi.org/10.1002/(SICI)1097-4539(199705)26:3<132::AID-XRS223>3.0.CO;2$\underline{\mathrm{L}}$

[17] Sear, L.G. (1997) The Fusion of Difficult Materials Including Chromite. Cassiterite and Reduced Sulphur. X-Ray Spectrometry, 26, 105-110. https://doi.org/10.1002/(SICI)1097-4539(199705)26:3<105::AID-XRS218>3.0.CO;21

[18] Bangladesh Agricultural Research Council (BARC) (2015) Fertilizer Recommendation Guide. Farmgate, New Airport Road, Dhaka, 1215.

[19] Goudie, A.S. and Midelton, N.J. (2006) Desert Dust in the Global System. Springer Berlin, Heidelberg, Berlin.

[20] Moslehuddin, A.Z.M., Hussain, M.S., Saheed, S.M. and Egashira, K. (1999) Clay Mineral Distribution Incorrespondence with Agroecological Regions of Bangladesh Soils. Clay Science, 11, 83-94.

[21] Giarola, N.F.B., Lima, H.V., Romero, R.E., Brinatti, A.M. and Silva, A.P. (2009) Crystallography and Mineralogy of the Clay Fraction of Hardsetting Horizons in Soils of Coastal Tablelands in Brazil. Brazilian Society of Soil Science, 33, 33-40.

[22] Egashira, K. and Yasmin, M. (1990) Clay Mineralogical Composition of Floodplainsoils of Bangladesh in Relation to Physiographic Units. Bulletin of the Institute of Tropical Agriculture Kyusho University, 13, 105-126.

[23] Alam, M.L., Miyauchi, N. and Shinagawa, A. (1993) Study on Clay Mineralogical Characteristics of Calcareous and Noncalcareous Soils of Bangladesh. Clay Science, 9, 81-97. 